\title{
MENINGKATKAN ADVERSITY QUOTIENT (DAYA JUANG) PADA ANAK ANAK PANTI ASUHAN MELALUI PENGUATAN SOSIAL SUPPORT
}

\author{
Latifah Nur Ahyani \\ Fakultas Psikologi, Universitas Muria Kudus \\ latifah.nur@umk.ac.id
}

\begin{abstract}
Abstrak
Penelitian ini bertujuan untuk menguji secara empiris efektifitas pelatihan social support dalam meningkatkan Adversity Quotient (daya juang) pada anak anak Panti Asuhan. Hipotesis yang diajukan dalam penelitian ini adalah sebagai berikut Ada perbedaan tingkat Adversity Quotient sebelum mendapatkan pelatihan social support dan setelah mendapatkan pelatihan social support. Tingkat Adversity Qoutient sebelum mendapatkan pelatihan social support lebih rendah dibandingkan tingkat Adversity Quotient setelah mendapatkan pelatihan social support. Alat ukur yang digunakan dalam penelitian ini adalah skala Adiversity Qoutient yang sudah dimodifikasi. Subjek penelitian adalah remaja panti asuhan Samsah di Kudus. Pengambilan sampel dengan purposive sampling dan diperoleh 12 anak sebagai sampel. Penelitian ini menggunakan metode penelitian kuantitiatif dengan rancangan One group Pretest and Posttest design (Cook \& Campbell, 1979). Hasil dari kegiatan yang telah dilakukan diuji statistik dengan uji $t$ diperoleh hasil $t$ : - 5,698 dengan nilai $p: 0,000$ ( $p$ 0,000), hal ini menunjukkan ada perbedaan yang signifikan antara Adversity Quotient sebelum pelatihan dengan Adversity quotient setelah pelatihan.
\end{abstract}

Kata Kunci: Adversity Quotient (daya juang), Pelatihan social support

\begin{abstract}
Purpose of this study is to test empirically the effectiveness of the training of social support in improving the Adversity Quotient (fighting spirit) in children Orphanage. The hypothesis of this study are as follows. There are differences in the level of Adversity Quotient before training social support and social support after receiving training. Adversity level Qoutient before training social support is lower than the level of Adversity Quotient after getting training of social support. Measuring instrument used in this study is the scale Adversity Qoutient modified. Subjects were orphaned teenaged Samsah in Kudus. Sampling with purposive sampling and obtained 12 children in the sample. This study used quantitative research methods to design One group pretest and posttest design (Cook \& Campbell, 1979). The results of the activities that have been done statistically tested by $t$ test result $t:-5.698$ with $p$ value: 0.000 ( $p \quad 0,000)$, it showed no significant difference between Adversity Quotient before training with Adversity Quotient after training.
\end{abstract}

Keyword: Adversity Quotient, the training of social support

\section{PENDAHULUAN}

Kehadiran orang tua dalam perkembangan jiwa anak sangat penting. Anak yang kehilangan orang tua maka anak tersebut dalam proses tumbuh kembangnya akan kehilangan 
hak untuk di bina dan di bimbing, diberikan kasih sayang, perhatian dan sebagainya. Kematian orang tua merupakan psikotrauma bagi anak yang sedang berkembang. Kehilangan cinta dan kasih sayang orang tua seringkali diikuti kecemasan dan depresi pada anak. Kematian salah satu orang tau akan memepengaruhi perkembangan mental anak. Bagaimana dampaknya tergantung pada siapa yang meninggal (ayah atau ibu), pada usia berapa ditinggalkan dan reaksi anak pun berbeda antara anak laki-laki dan anak perempuan (Lestari, 2003).

Berdasarkan hasil interview baik dengan anak anak panti maupun dengan para staf pendidik dipanti asuhan, diketahui anak-anak panti asuhan sering merasa binggung terkait masa depan, tidak memiliki pandangan yang jelas terkait keinginan. Ketika ditanya terkait mengapa mereka tidak mengetahuinya, mereka hanya menjawab jika kondisi mereka berbeda, mereka berfikir tidak ada yang membimbing, melindungi mereka.

Anak-anak panti asuhan merasa mereka butuh sesuatu yang bisa membuat mereka semangat untuk melakukan hal-hal dalam hidup mereka, mereka membutuhkan dukungan, penyemangat. Anak-anak panti asuhan menginginkan seperti anak yang lain yang memiliki orang tua, mereka ingin mendapatkan kasih sayang, kehangatan dari lingkungan.

Berdasarkan informasi dari pihak staf pendidik, anak-anak panti asuhan sering mengesampingkan jika ada tugas dari sekolah dengan alasan sudah di kerjakan tetapi tidak bisa dan tidak mengupayakan tugasnya selesai. Selain itu mereka jika ada masalah sering mengabaikannya, kurang berusaha untuk menyelesaikannya.

Permasalahan terkait anak-anak panti asuhan adalah sering mengabaikan masalah, tugas - tugas yang menjadi tanggung jawabnya, karena hal tersebut terkait dengan masa depan anak- anak tersebut. Hal ini juga menjadi parameter jika daya juang anak-anak panti tersebut rendah dan perlu untuk ditingkatkan.Selain itu anak - anak panti asuhan juga membutuhkan sesuatu yang dapat membuat mereka semangat untuk melakukan hal - hal dalam hidup mereka, mereka membutuhkan dukungan, penyemangat. Dalam kasus ini, sangat terlihat kaitannya dengan kehadiran orang terdekat seperti keluarga inti, orang tua, kerabat yang kedekatan secara emosional kurang mereka dapatkan atau bahkan sebagian besar diantara mereka sudah tidak memilikinya, sehingga wajar jika mereka kurang memiliki semangat, dorongan, karena mereka kurang mendapatkan perhatian kasih sayang, support dari orang terdekat. Hal tersebut dapat menjadi penyebab dalam penyelesaian masalah yang kurang baik, tidak ada motivasi, dan pandangan masa depan yang kurang baik juga.

Menurut Dalimunthe (2009) pemisahan anak dari keluarga dapat menimbulkan tekanan, akibat perubahan situasi hidup yang bersumber dari pengalaman kehilangan figur lekat anak jika berada pada situasi baru atau situasi yang tidak dikenalnya, tidak dapat diperkirakan apa yang 
akan dihadapi selanjutnya, perubahan kebiasaan, dan terpisah dari figur lekat. Reaksi anak dalam menghadapi perpisahan bervariasi dari mulai depresi berat, tidak ada reaksi atau biasa saja. Reaksi awal anak ini sangat dipengaruhi oleh berbagai faktor antara lain kondisi keterikatan emosional (attachment) dengan orang tua, kondisi pengasuh baru, pengalaman terdahulu anak dengan orang baru, jumlah dan lamanya perpisahan terdahulu, umur dan tingkat kematangan perkembangan anak (kognitif, emosi, sosial) (Rahmawan, 2010).

Menurut Santrock (2002) bahwa kematian orang orang yang dicintai memang merupakan suatu kehilangan yang sangat besar pengaruhnya terhadap individu. Kematian orang tua merupakan suatu hal yang sangat sakit untuk dihadapi oleh seorang anak, apalagi jika peristiwa kematian orang tua itu terjadi pada saat seorang anak sedang berada dalam tahap remaja, pada saat transisi dari tahap kanak kanak ke tahap dewasa. Selama periode ini seorang remaja berada di dalam masa transisi dari masih tergantung sebagai seorang anak menjadi dapat berdiri sendiri sebagai orang dewasa ( Astuti, 2009).

Untuk mengatasi permasalahan yang dihadapi dibutuhkan Adversity Quotient (daya juang) pada seorang anak yang kehilangan orang tua. Adversity Quotientatau kecerdasan adversitas merupakan pemahaman penting tentang apa yang dibutuhkan untuk mencapai kesuksesan. Sukses tidaknya individu dalam kehidupan ditentukan oleh kecerdasan adversitas, dimana kecerdasan adversitas dapat memberitahukan sejauhmana individu mampu bertahan dan mengatasi kesulitan yang dihadapi, individu mana yang mampu mengatasi kesulitan dan yang tidak mampu, individu mana yang akan memenuhi harapan dan potensi serta yang akan gagal, individu yang akan menyerah dan yang akan bertahan (Nur, 2014).

Menurut Stoltz (2000) kecerdasan adversitas adalah suatu kemampuan untuk mengubah hambatan menjadi suatu peluang keberhasilan mencapai tujuan. Kecerdasan adversitas mempengaruhi pengetahuan, kreativitas, produktivitas, kinerja, usia, motivasi, pengambilan resiko, perbaikan, energi, vitalitas, stamina, kesehatan, dan kesuksesan dalam pekerjaan yang dihadapi.

Berdasarkan hasil penelitian yang dilakukan oleh Nur (2014) yang berjudul "Hubungan antara Adversity Quotient dan Motivasi Berprestasi Siswa Kelas XI MA Ali Maksum Krapyak Yogyakarta" yang menunjukkan bahwa ada hubungan positif antara Adversity Quotient dengan motivasi berprestasi.

Menurut Stoltz (2000) setiap individu memiliki kecerdasan adversitas yang tinggi dan rendah. Adapun karakteristik individu yang memiliki kecerdasan adversitas tinggi, antara lain optimis, gigih, dan ulet dalam menghadapi masalah, berpikir dan bertindak secara matang dan bijaksana, dapat memotivasi diri sendiri, berani mengambil resiko dalam menghadapi tantangan 
dan perubahan hidup, bekerja dengan semangat tinggi, berorientasi pada masa depan dan memiliki komitmen untuk maju, disiplin, mengatakan hal-hal yang optimis dalam menghadapi masalah.

Stoltz (2000) juga mengungkapkan karakteristik individu yang memiliki kecerdasan adversitas rendah, yaitu pesimis dan mudah frustrasi dalam menghadapi masalah, berpikir dan bertindak cenderung tidak kreatif dan tidak berani mengambil resiko, menyalahkan orang lain sebagai penyebab suatu masalah atau kesulitan, cenderung lari dari masalah yang dihadapi, bekerja dengan tidak semangat dan tidak ambisius, cenderung emosional dalam melakukan pekerjaan, tidak berorientasi pada masa depan dan menghindari tantangan, mengatakan hal-hal yang pesimis dalam menghadapi masalah.

Carol Dweck, seorang profesor Jurusan Psikologi di University of Illinois, mengemukakan bahwa respon seseorang terhadap kesulitan terbentuk lewat pengaruh-pengaruh dari orang tua, guru, teman sebaya dan orang orang yang mempunyai peran penting selama masa kanak-kanak (Stoltz, 2000). Hal ini menunjukkan bahwa orang tua, guru dan teman sebaya memiliki peran penting dalam membentuk Adversity Quotient anak (Lestari, 2003).

Salah satu bentuk lingkungan yang diharapkan untuk meningkatkan Adversity Quotient adalah dukungan dari orang lain atau social support. Dukungan sosial bisa berasal dari keluarga, teman ataupun orang-orang tersayang seperti kekasih. Gentry dkk. (Sarafino, 2006) menggambarkan dukungan sosial sebagai suatu kenyamanan, perhatian, penghargaan ataupun bantuan yang diterima individu dari orang lain maupun kelompok. Adapun Cobb (Nietzel dan Bernstein, 1987) menyatakan bahwa dukungan sosial merupakan pengalaman yang membawa individu menyakini bahwa mereka diperhatikan, dicintai, dihargai, dan menjadi anggota jaringan komunikasi.

Sarafino (Smet, 1994) berpendapat bahwa dukungan sosial mengacu pada kesenangan yang dirasakan, penghargaan akan kepedulian, atau membantu orang menerima dari orangorang atau kelompok-kelompok lain. Uchino (Sarafino dan Smith, 2012) juga berpendapat bahwa dukungan sosial dapat diartikan sebagai kenyamanan, perlindungan, penghargaan, atau bantuan yang tersedia untuk seseorang dari orang lain atau kelompok. Adapun Gottielb (Smet, 1994), menyatakan bahwa dukungan sosial terdiri dari : 1) Informasi atau nasehat verbal dan/atau nonverbal yaitu bentuk dukungan sosial seperti memberikan informasi, nasehat, sugesti, petunjuk dan umpan balik. Mengenai apa yang sebaiknya dilakukan oleh orang lain yang membutuhkan. 2) Bantuan nyata atau tindakan yang diberikan oleh keakraban sosial atau didapat karena kehadiran mereka yaitu dukungan sosial yang bersifat secara langsung misalnya bantuan 
peralatan, pekerjaan dan keuangan. 3) Mempunyai manfaat emosional atau efek perilaku bagi pihak penerima.

Keberadaan dukungan adalah suatu hal yang penting karena dengan adanya dukungan tersebut anak akan menjadi lebih kuat dan mereka mampu mengatasi hambatan yang ada. Anak merasa seseorang peduli dengan apa yang sedang dihadapi oleh mereka. Mereka tidak merasa sendiri dalam menghadapi masalah tersebut. Hal ini sangat penting terutama bagi remaja awal yang cenderung lebih sulit untuk mengatasi perubahan yang ada karena masih sedikit pengalaman yang dimiliki. Napitupulu, Nashori, Kurniawan (2007) mengemukakan pada dasarnya setiap anak memerlukan dorongan dari orang disekitarnya apabila mereka merasa tidak mampu menghadapi masalah atau situasi tertentu.

\section{METODE PENELITIAN}

Rancangan penelitian ini menggunakan model One group Pretest and Posttest design (Cook \& Campbell, 1979). Desain ini menggunakan satu kelompok yang diamati sebagai kelompok eksperimen. Pengukuran dilakukan satu kali yaitu sebelum diberikan perlakuan (pretest) dan sesudah diberikan perlakuan (post-test).

\section{Desain Rancangan Eksperimen}

$\begin{array}{llll}\mathrm{KE} & \mathrm{O}_{1} & \mathrm{X} & \mathrm{O}_{2}\end{array}$

Keterangan :

KE : Kelompok Eksperimen

$\mathrm{O}_{1} \quad$ : Pre-test adversity quotient

$\mathrm{O}_{2} \quad$ : Post-test adversity quotient

$\mathrm{X} \quad$ : social support

Tahapan kegiatan ini:

1. Identifikasi bagaimanaAdversity quotient (daya juang) dan social support pada anak anak panti asuhan

2. Penyiapan materi ini dilakukan dalam waktu satu bulan dengan materi yang berbeda-beda, disesuaikan dengan kondisi yang aktual. Beberapa materi yang disiapkan adalah melatih mengelola emosi, penyelesaian masalah, manajeman kemarahan yang dituangkan. 
3. Pelaksaaan pemberikan psikoedukasi, bimbingan konseling, sharing pengalaman, psikogame pada anak anak panti asuhanakan berlangsung dalam waktu empat minggu berhubungan dengan materi-materi yang sudah disiapkan dan tema ini akan berkembang sesuai dengan situasi dan kondisi di panti asuhan.

4. Pengukuran sebelum dan setelah pemberian perlakuan atau post test pada Adversity quotient (daya juang) anak anak panti asuhan.

Khalayak sasaran dalam kegiatan ini adalah anak-anak panti asuhan. Anak anak panti juga memiliki hak yang sama dengan anak anak yang lain dan merupakan tanggung jawab kita bersama untuk membantu mereka dalam memperoleh hak ketenangan, kebahagiaan, kebersamaan, berperan dalam masyarakat, karena mereka juga aset bangsa.

\section{HASIL DAN PEMBAHASAN}

Berdasarkan hasil analisis data diperoleh hasil sebagai berikut

NPar Tests

\section{Descriptive Statistics}

\begin{tabular}{|l|r|r|r|r|r|}
\hline & N & Mean & Std. Deviation & Minimum & Maximum \\
\hline Pre_AQ & 11 & 125.45 & 12.644 & 108 & 144 \\
Post_AQ & 11 & 136.45 & 11.699 & 118 & 155 \\
\hline
\end{tabular}

One-Sample Kolmogorov-Smirnov Test

\begin{tabular}{|ll|r|r|}
\hline & & Pre_AQ & Post_AQ \\
\hline $\mathrm{N}$ & & 11 & 11 \\
Normal Parameters a,b & Mean & 125.45 & 136.45 \\
& Std. Deviation & 12.644 & 11.699 \\
Most Extreme & Absolute & .201 & .162 \\
Differences & Positive & .201 & .162 \\
& Negative & -.152 & -.156 \\
Kolmogorov-Smirnov Z & & .668 & .536 \\
Asymp. Sig. (2-tailed) & & .764 & .936 \\
\hline
\end{tabular}

a. Test distribution is Normal.

b. Calculated from data. 
Paired Samples Statistics

\begin{tabular}{|c|c|c|c|c|c|}
\hline & & Mean & $\mathrm{N}$ & Std. Deviation & $\begin{array}{c}\text { Std. Error } \\
\text { Mean }\end{array}$ \\
\hline \multirow{2}{*}{$\begin{array}{l}\text { Pair } \\
1\end{array}$} & Pre_AQ & 125.45 & 11 & 12.644 & 3.812 \\
\hline & Post_AQ & 136.45 & 11 & 11.699 & 3.527 \\
\hline
\end{tabular}

Paired Samples Correlations

\begin{tabular}{|ll|r|r|r|}
\hline & & N & Correlation & Sig. \\
\hline Pair 1 & Pre_AQ \& Post_AQ & 11 & .864 & .001 \\
\hline
\end{tabular}

Paired Samples Test

\begin{tabular}{|c|c|c|c|c|c|c|c|c|}
\hline & \multicolumn{5}{|c|}{ Paired Differences } & \multirow[b]{3}{*}{$\mathrm{t}$} & \multirow[b]{3}{*}{$\mathrm{df}$} & \multirow[b]{3}{*}{ Sig. (2-taile } \\
\hline & \multirow[b]{2}{*}{ Mean } & \multirow[b]{2}{*}{ Std. Deviati } & \multirow{2}{*}{$\begin{array}{c}\text { Std. Erro } \\
\text { Mean }\end{array}$} & \multicolumn{2}{|c|}{$\begin{array}{c}95 \% \text { Confidenc } \\
\text { Interval of the } \\
\text { Difference }\end{array}$} & & & \\
\hline & & & & Lower & Upper & & & \\
\hline Pair 1 Pre_AQ - Post & -11.000 & 6.403 & 1.931 & -15.304 & -6.698 & -5.698 & 10 & .000 \\
\hline
\end{tabular}

Uji normalitas dilakukan untuk mengetahui apakah setiap variabel terdistribusi (tersebar) secara normal. Uji normalitas menggunakan teknik One Sample KolmogorovSmirnov Test dari program SPSS 12.00 for Windows ini diperoleh sebaran skor pada variabel adversity quotient adalah normal $(\mathrm{K}-\mathrm{S} Z=0.764 ; p=0.936$ atau $p>0.05)$. Hal tersebut menunjukkan bahwa memiliki sebaran data yang normal.

Berdasarkan hasil analisis dengan menggunakan uji t diperoleh hasil t : - 5,698 dengan nilai $p: 0,000$ ( $p \quad 0,000$ ), hal ini menunjukkan ada perbedaan yang signifikan antara Adversity Quotient sebelum pelatihan dengan Adversity quotient setelah pelatihan.

Hal ini sesuai dengan Carol Dweck (Stoltz, 2000) yang menyatakan bahwa respons seseorang terhadap kesulitan dipengaruhi oleh peran orangtua, guru, teman sebaya dan orang-orang penting lainnya. Hal tersebut menguangkapkan bahwa semakin banyak dukungan sosial yang diperoleh maka mengakibatkan seseorang lebih mampu bertahan dan bangkit dari masalah yang sedang dihadapinya. Individu tidak merasa sendiri, muncul semangat untuk dapat 
menjadi yang lebih baik dari sebelumnya, dan lebih optimis dalam mengsikapi masalah yang sedang dihadapinya.

Dukungan sosial yang dimaksud dalam penelitian ini disamping melibatkan anak-anak panti juga para guru dan care giver yang berada di lingkungan panti asuhan, karena mereka adalah sosok pengganti dari orang tua anak anak panti asuhan. Care giver dan para guru dapat memberikan sosial support sebagaimana layaknya orangtua maupun sahabat bagi anak-anak panti, tempat berbagi dan membimbing anak - anak. sehingga mereka lebih merasa terayomi, dengan harapan anak - anak dapat berkembang lebih optimal pada sisi psikologisnya khususnya Adversity Quotient.

Secara keseluruhan, dukungan sosial yang positif dan berkualitas dapat meningkatkan ketahanan stres, membantu melindungi terhadap dampak terkait trauma psikopatologi, mengurangi konsekuensi fungsional gangguan akibat luka, seperti posttraumatic stress disorder (PTSD), dan mengurangi penyakit medis dan kematian (Ozbay, Johnson, Dkk, 2007).

\section{SIMPULAN}

Anak - anak panti sangat membutuhkan dukungan moral maupun material. Dukungan sosial sendiri sangat dibutuhkan melihat kondisi anak - anak panti asuhan yang kurang beruntung. Mereka hidup dalam keterbatasan. Selain membutuhkan perhatian, mereka juga membutuhkan teman untuk berbagi, berkeluh kesah, sharing, juga seseorang yang memotivasi, agar tidak merasa rendah diri sehingga dapat menstimulus anak berkembang optimal dalam segala aspek.

\section{DAFTAR PUSTAKA}

Agustian, A.G. (2001). Rahasia Sukses Membangun Kecerdasan Emosi dan Spiritual ESQ: Emotional Quotient Berdasarkan Enam Rukun Iman dan Lima Rukun Islam. Jakarta: Arga

Dalimunthe, K. (2009). Kajian Mengenai Kondisi Psikososial Anak Yang Dibesarkan Di Panti Asuhan. Universitas Padjajaran Bandung.

Lestary, L.S. (2003). Hubungan antarapersepsi terhadap peran ibu dengan AQ pada remaja. Skripsi (Tidak Diterbitkan). Yogyakarta: Fakultas Psikologi \& IImu Sosial Budaya, Universitas Islam Indonesia.

Napitupulu, L., Nashori, H. F., \& Kurniawan, I.N. (2007). Pelatihan Adversity Intelligence untuk Meningkatkan Kebermaknaan Hidup Remaja Panti Asuhan. Jurnal Pemikiran dan Penelitian Psikologi Psikologika, No. 12, Vol. 2, Hal: 43-56. 
Nietzel, M.T. \& Berstein, D.A. (1987) . Introduction to Clinical Psychology. Second ed., New Jersey: Prentice-Hall Inc.

Nur. S. (2014). Hubungan Antara Adversity Quotient Dan Motivasi Berprestasi Siswa Kelas Xi Ma Ali Maksum Krapyak Yogyakarta. Skripsi Thesis. Yogyakarta : Fakultas ilmu sosial dan humaniora. Universitas Islam Negeri Sunan Kalijaga.

Ozbay, F., Johnson, D.C., Dimoulas, E., Morgan, C.A., Charney, D., Southwick, S. (2007). Social Support and Resilience to Stress. Journal Psychiatry.New York : MMC.

Sarafino, E.P. (2006). Health Psychology Biopsychosocial Interaction. Fifth ed. USA: John Wiley $\&$ Sons.

Sarafino, E.P \& Smith, T.W. (2012). Health Psychology Biopsychosocial Interactions. Seventh ed. USA: John Willey \& Sons (Asia) Pte Ltd.

Smet, B. (1994). Psikologi Kesehatan. Jakarta: Grasindo.

Stoltz, P. G. (2000). Adversity quotient mengubah hambatan menjadi peluang. Alih bahasa T. Hermaya. Jakarta: PT Gramedia Widiasarana Indonesia. 